\title{
PARTISIPASI PEDAGANG DALAM MENJAGA KEBERSIHAN LINGKUNGAN PASAR AUR KUNING KOTA BUKITTINGGI
}

\author{
Reji Anggraini ${ }^{1}$ Iswandi $^{2}$ Deded Chandra ${ }^{2}$ \\ Program Studi Pendidikan Geografi \\ Jurusan Geografi \\ Fakultas Ilmu Sosial \\ Universitas Negeri Padang \\ Email: rejianggraini94@gmail.com
}

\begin{abstract}
ABSTRAK
Penelitian ini bertujuan untuk mendeskripsikan partisipasi pedagang dalam menjaga kebersihan lingkungan pasar, faktor-faktor yang mempengaruhi partisipasi pedagang dalam menjaga kebersihan lingkungan pasar khususnya di Pasar Aur Kuning Kota Bukittinggi. Jenis penelitian adalah penelitian deskriptif kualitatif. Informan penelitian yaitu pedagang yang berjualan di Pasar Aur Kuning, Dinas Koperasi dan Perdagangan Kota Bukittinggi menggunakan teknik snowball sampling. Teknik pengambilan data yaitu dengan observasi lapangan, wawancara dan dokumentasi. Dari hasil penelitian menunjukan bahwa : (1) Pedagang di Pasar Aur Kuning Kota Bukittinggi kurang berpatisipasi dan mengetahui pentingnya menjaga kebersihan bagi kelangsungan hidup mereka terutama bagi kesehatan, untuk menumbuhkan kesadaran dalam diri itu susah terutama kebiasaan membuang sampah dan menjaga kebersihan lingkungan. (2) Faktor yang mempengaruhi partisipasi pedagang dalam menjaga kebersihan lingkungan pasar, meliputi faktor internal yaitu pendidikan pedagang dan jenis dagangan berpengaruh terhadap perilaku serta pengetahuan pedagang terhadap kebersihan, faktor eksternalnya meliputi peraturan, kondisi dan fasilitas yang disediakan pengelola pasar menunjang partisipasi yang dilakukan pedagang yang masih terbilang rendah dan masih kurang dalam pengadaannya.
\end{abstract}

Kata Kunci: Partisipasi, Pedagang, Kebersihan Lingkungan

\section{ABSTRACT}

This study aims to describe the participation traders in maintaining the cleanliness of the market environment, the factors that influence the participation of traders in maintaining the cleanliness of the market environment, especially in Aur Kuning Market, Bukittinggi City. The type of research used is descriptive qualitative research. Informant of research are traders who sell in Aur Kuning Market, Department of Cooperatives and Trade 1Bukittinggi City. Using snowball sampling technique. Technique of data retrieval is by field observation, interview and documentation.From the results of the research shows that: (1) In general, traders in Pasar Aur Kuning Bukittinggi City have participated and know the importance of maintaining hygiene for their survival, especially for health, but to raise awareness within it is difficult especially the habit of disposing of garbage and maintaining the cleanliness of the environment. (2) Factors that influence the participation of traders in maintaining the cleanliness of the market environment, including internal factors of merchant education and the type of merchandise affect the behavior and knowledge of traders on cleanliness, external factors include regulations, conditions and facilities provided by market managers to support the participation of traders which is still relatively low and still lacking in procurement.

Keyword: Participation, Traders, The Cleanliness of The Environment

\footnotetext{
${ }^{1}$ Mahasiswa Program Studi Pendidikan Geografi Fakultas Ilmu Sosial Universitas Negeri Padang

${ }^{2}$ Dosen Jurusan Geografi Fakultas Ilmu Sosial Universitas Negeri Padang
} 


\section{PENDAHULUAN}

Pasar merupakan pusat dari sebuah kota, pasarsangat penting bagi sebuah kota. Kondisi pasar yang baik adalah hasil pengaturan rencana tata ruang yang baik. Begitu juga sebaliknya, jika pengaturan rencana tata ruang kurang baik secara tidak langsung berimbas kepada kondisi pasar yang kurang baik juga. Pasar Aur Kuning Bukittinggi sebagai salah satu pusat perdagangan terbesar yang terdapat di Kota Bukittinggi tidak hanya memberikan manfaat bagi masyarakat, tetapi juga menimbulkan masalah yang sangat kompleks.

Raharjo (1985) menyatakan bahwa partisipasi dapat diartikan sebagai keikutsertaan masyarakat dalam programprogram pemerintah. Kemudian menurut Hanafiah (1982) bahwa peran serta tidak hanya pengertian ditingkat lokal seperti turut serta, bersama atau individu, dalam proyek pemerintah atau tidak hanya dalam hubungan produksi, pengambilan keputusan dan pelaksanaan tetapi harus lebih luas. Sedangkan Slamet (1985) mengemukakan bahwa untuk terjadinya partisipasi perlu adanya kesempatan untuk berpartisipasi dan adanya kemauan dari setiap individu.

Partisipasi pedagang berarti keikutsertaan untuk membantu berhasilnya setiap program sesuai dengan kemampuan setiap orang tanpa berarti mengorbankan kepentingan diri sendiri. Partisipasi pedagang dalam menjaga kebersihan pasar merupakan keikutsertaan pedagang dalam program-program pemerintah khususnya di pasar misalnya tentang hal kebersihan lingkungan pasar.

Menurut Dacana (1996) dalam kaitannya dengan masalah kebersihan lingkungan mengatakan bahwa masalah budaya hidup sehat erat kaitannya dengan masalah kebersihan lingkungan. Dimana merupakan salah satu indikator untuk mengukur tingkat kedisiplinan dalam kehidupan sosialnya di lingkungan masyarakat. Lingkungan yang bersih dapat terwujud apabila dalam sikap dan perilaku demikian itu biasanya lahir dan dilatar belakangi oleh tingkat pengetahuan, kesadaran dan tingkat disiplin pribadi di tengah-tengah kehidupan masyarakat. Disamping itu kebiasaan hidup yang bersih dan tertib merupakan hasil dari proses panjang transformasi sistem nilai, baik nilai budaya maupun agama.

Lingkungan menurut Purwanto (1999) digolongkan menjadi beberapa bagian yaitu: a) lingkungan manusia, yaitu termasuk didalamnya adalah lingkungan keluarga, sekolah dan masyarakat, juga kebudayaan, agama, taraf kehidupan dan sebagainya, b)lingkungan benda, yaitu benda yang terdapat di sekitar manusia yang turut memberi warna pada jiwa manusia yang ada di sekitar mereka dan c) lingkungan geografis, yaitu bahwa latar geografis turut mempengaruhi corak kehidupan manusia. Misalnya manusia yang tinggal didaerah pantai mempunyai keahlian, kegemaran dan kebudayaan yang berbeda dengan manusia yang ada dan tinggal didaerah gunung.

Pasar adalah tempat para penjual dan pembeli saling berhubungan dengan mudah untuk melakukan transaksi pedagangan (Ensiklopedi Indonesia). Dalam pengertian yang terbatas pasar adalah tempat tertentu, pasar memperjual belikan suatu barang biasanya dan terutama barang-barang keperluan hidup. Menurut Suparlan (1981) pasar adalah sekelompok bangunan yang sebagian beratap dan terbuka tanpa atap yang ditunjuk oleh pemerintah dimana pedagang 
berkumpul untuk memperdagangkan dan menjual barang dagangannya.

Menurut Azwar (1979) sampah merupakan sebagian dari sesuatu yang tidak dipakai, tidak disenangi atau sesuatu yang harus dibuang, yang umumnya berasal dari kegiatan manusia. Sukarni (1994) mengatakan yang dimaksud dengan sampah adalah semua zat atau benda yang sudah tidak terpakai lagi baik yang berasal dari rumah tangga atau hasil proses industri.

Didalam usaha penanganan masalah kebersihan pasar di Pasar Aur Kuning Bukittinggi, pemerintah daerah telah berusaha secara maksimal dengan menyediakan fasilitas yang cukup, baik sarana dan prasarana seperti menyediakan truk-truk sampah, tempat sampah, gerobak, dan lain-lain sebagai penunjang. Tetapi tampaknya usaha tersebut masih perlu ditingkatkan lagi dengan melakukan berbagai penyuluhan mengenai kebersihan khususnya kepada para pedagang dan pengunjung/pembeli. Bagaimanapun besarnya usaha yang dilakukan pemerintah jika tidak ada partisipasi dari pedagang dan pengunjung/pembeli maka usaha tersebut tidak akan berhasil.

Permasalahan yang ditemui berkaitan dengan perilaku pedagang adalah sampah yang dihasilkan dari sisa dagangan dibiarkan saja menumpuk di sekitar tempat mereka berjualan. Hal ini mengakibatkan terganggunya pemandangan dan juga bau tidak sedap yang diakibatkan dari sampah yang dibiarkan tersebut. Berdasarkan wawancara peneliti dengan Dinas Pengelola Pasar terhadap pedagang diperoleh informasi bahwa kurangnya respon yang baik dari pedagang jika diberikan penyuluhan tentang kebersihan dari dinas.

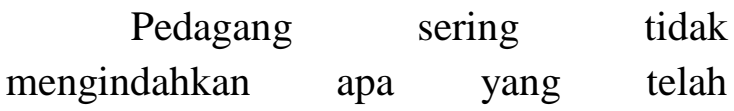
diberitahukan oleh dinas, seperti untuk tidak membuang sisa sampah dagangan sembarangan diarea pasar sehingga kondisi pasar kumuh dan kotor. Menarik untuk dijadikan sebuah kajian ilmiah, berdasarkan uraian diatas maka penulis tertarik untuk meneliti dan mengambil judul penelitian tentang "Partisipasi Pedagang Dalam Menjaga Kebersihan Lingkungan Pasar Aur Kuning Kota Bukittinggi”.

\section{METODE PENELITIAN}

Penelitian ini menggunakan jenis penelitian deskriptif kualitatif. Menurut Nasution dalam Sugiyono (2005) bahwa penelitian kualitiatif pada hakekatnya adalah mengamati orang dalam lingkungan hidupnya, berinteraksi dengan mereka, berusaha memahami bahasa tafsiran mereka tentang dunia sekitarnya. Penelitian deskriptif kualitatif diajukan untuk mendeskripsikan dan menggambarkan fenomena-fenomena yang ada, baik bersifat alamiah maupun rekayasa manusia, yang lebih memperhatikan mengenai karakteristik, kualitas, keterkaitan antar kegiatan.

Lokasi penelitian ini dilakukan diPasar Aur Kuning Kota Bukittinggi, lokasi ini sengaja dipilih karena peneliti ingin mengetahui bagaimana partisipasi pedagang tentang kebersihan lingkungan pasar. Waktu penelitian yang akan dilakukan pada bulan Desember 2017. Peta lokasi penelitian dapat dilihat pada gambar 1 . 


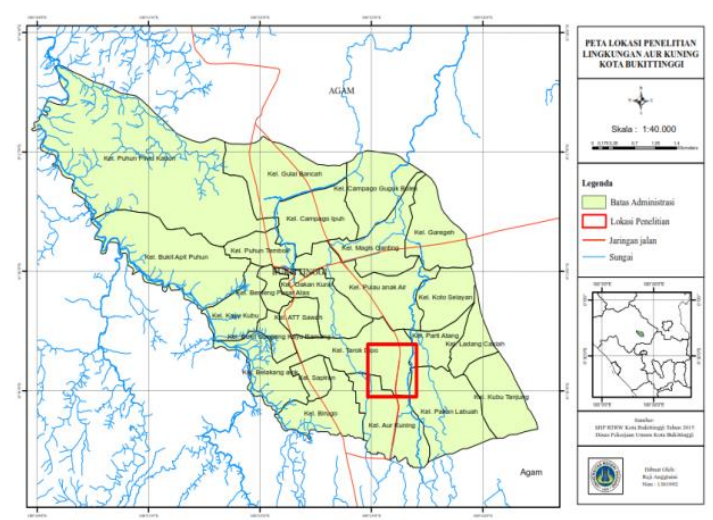

Gambar 1. Lokasi Penelitian

Informan dalam penelitian ini dipilih adalah pedagang yang berjualan di Pasar Aur Kuning Kota Bukittinggi yang berjumlah 20 orang. Dengan menggunakan teknik snowball sampling. Penentuan responden atau informan yang akan diambil informasinya haruslah sesuai dengan karakteristik penelitian kualitatif, yaitu dengan menetapkan informan kunci. Informan kunci diambil dari orang yang banyak mengetahui permasalahan penelitian.

Data yang diperoleh data primer adalah data yang diperoleh langsung dari sumber atau informan. Pengambilan data yang relevan dilakukan dengan menggunakan teknik pengumpulan data informasi dengan cara observasi, wawancara, dan dokumentasi.

\section{HASIL DAN PEMBAHASAN}

Hasil wawancara dan pengamatan yang peneliti lakukan di Pasar Aur Kuning Kota Bukittinggi diperoleh informasi bahwa :

\section{Partisipasi Pedagang Dalam}

Menjaga Kebersihan Lingkungan Pasar Aur Kuning Kota Bukittinggi. Budaya bersih oleh masyarakat di harapkan menjadi suatu kebiasaan bagi masyarakat khususnya pedagang di Pasar Aur Kuning. Pemahaman pedagang di Pasar Aur
Kuning mewakili perilaku dan pemahaman yang berbeda mengenai kedisiplinan dalam menjaga kebersihan, sehingga sikap kedisiplinan pedagang terhadap masalah kebersihan yang ada di lingkungan berbeda. Maka dari itu perlu adanya partisipasi pedagang pasar yang baik dalam bentuk tindakan maupun ide dalam menjaga kebersihan, hal ini untuk meminimalisir sampah bertebaran disekitar kios dan stand para pedagang sehingga dapat tercipta kebersihan lingkungan pasar. Kesadaran dan partisipasi pedagang dalam menjaga kebersihan masih kurang, terutama tentang sampah.

Berdasarkan hasil temuan dilapangan dan sesuai dengan tujuan penelitian menunjukkan bahwa tingkat kebersihan di Pasar Aur Kuning ini masih kurang karena masih banyak terdapat tumpukan sampah yang berserakan di tengah-tengah pasar atau di depan kios atau stand, hal ini disebabkan karena tidak adanya tempat sampah yang disediakan oleh Dinas Pasar disebagian tempat di Pasar Aur Kuning dan juga tempat penyediaan tempat sampah sementara bagi pedagang serta rendahnya kesadaran pedagang dalam menjaga kebersihan pasar dan kebiasaan pedagang. Sehingga masih banyak pedagang yang membuang membiarkan sampah bertebaran di depan kios mereka.

Berdasarkan hasil penelitian ini dapat disimpulkan bahwa pedagang pada umumnya tidak memiliki memiliki tempat sampah sendiri dan juga tidak memiliki waktu yang rutin untuk membersihkan toko/ kios dan stand mereka, bila ada waktu setelah berjualan mereka bersihkan. Alasannya mereka lebih mementingkan merapikan barang dagangannya dan melayani pembeli daripada memperhatikan kebersihan lingkungan sekitar tempat 
berjualan, membiasakan hidup bersih pada lingkungan pasar itu dimulai dari lingkungan rumah sendiri, karena itu perlunya kesadaran dalam diri setiap individu untuk peduli lingkungan, lingkungan pasar yang bersih merupakan dambaan semua pedagang. Namun tidak mudah untuk menciptakan lingkungan pasar terlihat bersih dan rapi sehingga nyaman dilihat dan pembeli pun nyaman berbelanja di pasar.

Dengan pendapat pedagang di Pasar Aur Kuning dapat disimpulkan bahwa pedagang di Pasar Aur Kuning tersebut sebenarnya peduli lingkungan dan ada juga yang ikut serta berpartisipasi langsung dalam menjaga kebersihan lingkungan pasar misalnya membuang sampah pada tempatnya, membersihkan toko/stand masing-masing sebelum dan setelah berjualan, membayar retribusi kebersihan setiap hari. Dari sekian banyak yang ikut berpartisipasi dalam menjaga kebersihan lingkungan pasar masih ada sebagian kecil dari mereka yang sama sekali tidak peduli dengan kebersihan lingkungan berjualan mereka, mereka lebih memilih untuk membiarkan saja dan tidak mau tahu tentang kebersihan sebab mereka mengatakan telah membayar retribusi kebersihan.

Tindakan lainnya para pedagang mengumpul sampah setiap hari dan pada sore hari pedagang mempersiapkan sampah dagangannya di depan kios masing-masing agar pada saat petugas kebersihan datang mengambil sampah mereka tidak repot lagi untuk mengumpulkan sampah dagangannya. Para pedagang di Pasar Aur Kuning sangat disiplin dalam hal mengurus dan membuang sampah dagangannya masingmasing karena Pasar Aur Kuning telah memiliki fasilitas mobil sampah dari Dinas
Kebersihan yang datang setiap hari untuk mengambil sampah para pedagang. Dengan adanya mobil sampah tersebut maka para pedagang tidak repot lagi membuang sampah ke tempat pembuangan sampah sementara, sehingga kebersihan di sekitar wilayah Pasar Aur Kuning terjamin.

Faktor Yang Mempengaruhi Partisipasi Pedagang Dalam Menjaga Kebersihan:

Faktor internal

1. Tingkat pendidikan

Tingkat pendidikan yang rata-rata sekolah tidak menyelesaikan pendidikannya, juga berpengaruh pada kemampuan berkomunikasi dan menyampaikan informasi dan penerimaan yang baik dari pedagang sebab kurangnya pengetahuan pedagang tentang dampak yang akan timbul jika lingkungan sekitar area berjualan kotor, contoh nyatanya kurangnya daya tarik pembeli untuk singgah membeli barang dagangan karena keadaan sekitar tempat berjualan kumuh. Pengetahuan tentang sampah meliputi jenis sampah, cara pengolahan dan pemanfaatan sampah, dampak dari sampah terhadap kesehatan dan dampak dari sampah terhadap lingkungan.

2. Jenis dagangan

Jenis dagangan yang dijual memiliki keterkaitan yang kuat dengan tingkat partisipasi pedagang dan kepedulian pedagang dalam menjaga kebersihan lingkungan. Dari pendapat yang saya dapatkan dari pedagang dapat ditarik kesimpulan bahwa jenis barang dagangan yang dijual pedagang bervariasi juga mempengaruhi kebersihan area sekitar berjualan, seperti pedagang sayur dan pedagang buah mereka tidak akan membersihkan area sekitar tempat berjualan karena akan berserakkan lagi karena sampah yang dihasilkan sampah 
organik, berbeda dengan pedagang lain yang berjualan kain, jam, dan lain-lain karena barang dagangan mereka menghasilkan sampah anorganik maka mereka selalu mengumpulkan sampah mereka.

Faktor eksternal

1. Peraturan

Berdasarkan wawancara yang peneliti lakukan dapat disimpulkan bahwa tidak adanya peraturan tertulis yang dibagikan oleh Dinas Pasar dalam hal menjaga kebersihan sehingga kesadaran pedagang masih rendah dalam melaksanakannya sehingga tidak heran disebagian area pasar masih ada sampah yang bertebaran dan pedagang tidak begitu peduli terhadap kebersihan pasar serta anggapan pedagang tentang masalah kebersihan merupakan tanggung jawab pengelola pasar.

2. Kondisi Lingkungan

Kondisi Pasar Aur Kuning dapat diamati dengan jelas sebagian tempat sangat terlihat bersih dan sebagian lagi terlihat sangat kotor karena berbedanya kesadaran, pemahaman dan partisipasi pedagang dalam menjaga kebersihan. Semua itu tergantung bagaimana pedagang menyikapi masalah kebersihan dan inisiatif pedagang itu sediri dalam menjaga kebersihan lingkungan Pasar Aur Kuning Kota Bukittinggi.

\section{Fasilitas}

Pada penelitan ini fasilitas yang ditinjau mencakupi bagaimana pengelola memperhatikan dan menyediakan fasilitas penunjang (tempat sampah) di lingkungan pasar, dan penyediaan tenaga kebersihan, dikarenakan tempat sampah/keranjang yang ada masih kurang dan tempat sampah/ keranjang hanya diletakkan pada tempat-tempat tertentu.

\section{PEMBAHASAN}

Berdasarkan hasil penelitian yang telah ditemui peneliti saat di lapangan melalui Observasi, Wawancara dan Dokumentasi maka diperoleh hasil penelitian sebagai berikut:

Pertama, partisipasi pedagang dalam menjaga kebersihan lingkungan diartikan sebagai tindakan yang dilakukan agar lingkungan pasar bersih dari sampah sehingga untuk mengatasi masalah kebersihan lingkungan pasar cukup dilakukan dengan membersihkan tempat sekitar berjualan masing-masing dengan menyapu dan menyediakan tempat sampah bila tidak ada tempat sampah yang disediakan pengelola pasar serta cukup menjaga kebersihan lingkungan tempat berjualan masing-masing.

Umumnya pedagang mengetahui dan menyadari pentingnya menerapkan budaya hidup bersih bagi kesehatan dan lingkungan. Akan tetapi pada kenyataannya antara pemahaman dan pengetahuan pedagang tidak sesuai dengan perilaku mereka. Kebiasaan membiarkan sampah yang berserakkan serta tidak adanya kesadaran akan menjaga kebersihan masih kurang terlihat dari tidak adanya tindakan nyata yang dilakukan pedagang sehingga masih ada sampah yang bertebaran.

Kedua, faktor yang mempengaruhi partisipasi pedagang dalam menjaga kebersihan lingkungan pasar yang merupakan ladang mereka dalam mencari rezeki dan memenuhi kebutuhan hidupnya. Salah satu faktor yang mempengaruhi partisipasi pedagang adalah faktor dari dalam diri pedagang yaitu tingkat pendidikan pedagang yang berdampak terhadap pengetahuan dan pemahaman pedagang dalam menjaga kebersihan. Tingkat pendidikan juga berpengaruh pada 
kemampuan berkomunikasi dan menyampaikan informasi dan penerimaan yang baik dari pedagang sebab kurangnya pengetahuan pedagang tentang dampak yang akan timbul jika lingkungan sekitar area berjualan kotor, contoh nyatanya kurangnya daya tarik pembeli untuk singgah membeli barang dagangan karena keadaan sekitar tempat berjualan kumuh.

Pengetahuan tentang sampah meliputi jenis sampah, cara pengolahan dan pemanfaatan sampah, dampak dari sampah terhadap kesehatan dan dampak dari sampah terhadap lingkungan. Faktor lainnya yaitu jenis barang dagangan yang dijual pedagangan serta faktor eksternal yang berasal dari pengelola berupa peraturan yang tidak tertulis jadi pengelola tidak bisa menyalahkan pedagang sepenuhnya apabila masih ada sampah yang berserakkan karena tidak adanya kejelasan terhadap peraturan, hal ini menyangkut inisiatif yang akan dilakukan pedagang dalam menjaga kebersihan lingkungan pasar. Kondisi pasar dan fasilitas yang disediakan oleh pengelola Pasar Aur Kuning Kota Bukittinggi yang belum lengkap. Fasilitas pembuangan sampah yang disediakan di Pasar Aur Kuning belum seluruhnya disediakan oleh pemerintah baru dibeberapa titik yang disediakan, selebihnya disiapkan sendiri oleh masing-masing pedagang dengan menggunakan kantong plastik bekas (assoy), karung bekas, tempat sampah yang dibeli sendiri yang diletakkan didepan toko/kios dan stand masingmasing untuk tempat penampungan sampah setiap hari petugas kebersihan datang mengambil sampah di depan kios para pedagang. Hal ini juga menyebabkan lingkungan pasar terlihat kurang bersih di tambah lagi ketidak pedulian pedagang terhadap kebersihan.
Namun dari hasil penelitian diketahui tempat sampah/keranjang hanya diletakkan pada tempat-tempat tertentu, hal ini karena keterbatasan area luas pasar dan dikhawatirkan akan mengganggu pembeli jika tempat sampah diletakkan setiap tempat. Untuk kondisi lingkungan mereka menganggap pihak pengelola telah memberikan perhatian. Ini dikarenakan adanya usaha dari pengelola untuk selalu memperhatikan kebersihan dengan melakukan pembersihan setiap beberapa jam dan adanya seorang yang khusus memperhatikan kondisi dari lingkungan, sehingga jika ada sampah bertumpuk atau berserakan akan memberikan peringatan ke pedagang dan petugas kebersihan.

Alam menyikapi sampah yang ada di area tempat berjualan umumnya pedagang membersihkan dengan cara menyapu yang kemudian dibuang ke tempat sampah yang telah di sediakan sendiri ataupun yang telah di sediakan pengelola pasar yang kemudian akan diangkut petugas kebersihan.

Hal ini didukung oleh dalam Djoyomartono (2004) Foster dan Anderson mengemukkan bahwa kesehatan berhubungan dengan perilaku. Perilaku manusia cenderung bersifat adaptif. Sadar atau tidak sadar perilaku itu direncanakan untuk mempertahankan kelangsungan hidupnya dan meningkatkan kesejahteraan anggota tiap kelompok. Perilaku sehat dapat dipandang sebagai suatu respon yang rasional terhadap hal-hal yang dapat mengakibatkan sakit sehingga adanya partisipasi yang dilakukan pedagang dalam menjaga kebersihan. Hal ini didukung oleh Purwanto (1999) mengartikan lingkungan dalam pergertian psikologi adalah segala apa yang berpengaruh pada diri individu dalam berprilaku, dan membentuk sikap dalam lingkungan masyarakat merupakan 
suatu tindakan yang sulit dan memerlukan adanya kerjasama (gotong royong) serta kesadaran dari masyarakat untuk ikut berpartisipasi dalam menjaga hidup bersih pada lingkungan. Sehingga dapat diaplikasi oleh masyarakat yang menjadi pedagang yang peduli terhadap kebersihan lingkungan pasar.

\section{PENUTUP}

\section{Kesimpulan}

Berdasarkan hasil penelitian dan pembahasan dalam penelitian mengenai partispasi pedagang dalam menjaga kebersihan lingkungan Pasar Aur Kuning Kota Bukittinggi dapat disimpulkan sebagai berikut:

1. Pedagang di Pasar Aur Kuning Kota Bukittinggi pada umumnya kurang berpartisipasi dalam menjaga kebersihan lingkungan pasar, dapat dilihat dari partisipasi dan kurangnya pemahaman serta kesadaran pedagang mengenai hidup bersih dan cara pedagang menjaga kebersihan lingkungan lewat tindakkan penyediaan peralatan kebersihan dan kepedulian mereka terhadap sampah, sebagian kecil dari mereka yang peduli dengan kebersihan pasar sehingga banyak sampah yang bertebaran.

2. Faktor yang mempengaruhi partisipasi pedagang dalam menjaga kebersihan lingkungan pasar, meliputi faktor internal yaitu pendidikan pedagang yang rata-rata rendah dan jenis dagangan berpengaruh terhadap perilaku serta pengetahuan pedagang terhadap kebersihan, faktor eksternal yang mempengaruhi peran serta pedagang adalah adanya bantuan teknis dari pemerintah meliputi peraturan, kondisi dan fasilitas yang disediakan pengelola pasar menunjang partisipasi yang dilakukan pedagang.

\section{Saran}

1. Pedagang Pasar Aur Kuning harus memperhatikan kembali bagaimana kebersihan pasar agar lebih bersih dan nyaman.Pedagang Pasar Aur Kuning disarankan agar mematuhi aturan-aturan yang telah dibuat oleh pemerintah daerah tentang ketertiban peraturan pasar dan meningkatkan kesadaran terhadap lingkungan pasar terciptanya lingkungan pasar yang lebih bersih dan nyaman untuk berdagang

1. Pemerintah yang bergerak dalam kesehatan masyarakat serta pengelola pasar memberikan perhatian mengenai masalah kebersihan lingkungan masyarakat khususnya dipasar, serta memberikan bantuan, berupa sarana dan fasilitas yang lengkap yang dapat mendorong pedagang untuk peduli dan menjaga kebersihan lingkungan pasar, karena hal itu sangat penting bagi kesehatan dan lingkungan berjualan mereka.

2. Adapun penelitian ini belum sepenuhnya sempurna, oleh karena itu peneliti berharap adanya tambahan-tambahan pada penelitian selanjutnya tentang kebersihan lingkungan pasar agar lebih terfokusnya penelitian ini. Adapun untuk penelitian dengan tema yang sama seharusnya lebih memfokuskan pada penelitian pada partisipasi pedagang dalam menjaga kebersihan lingkungan pasar serta pengelolaannya oleh pengelola pasar. 


\section{DAFTAR PUSTAKA}

Adisasmita, Raharjo. 1985. Dampak Pemisahan Sampah Domestik Organik dan Anorganik bagi Masyarakat Surabaya. Surabaya: Akademi Perawatan Kesehatan

Azwar, Asrul. 1979. Pengantar Ilmu

Kesehatan Masyarakat. Jakarta: Mutiara Sumber Widya

Dacana. 1996.Memproses Sampah. Jakarta: Penebar Swadaya

Djoyomartono, Mulyono. 2004. Antropologi Kesehatan. Semarang: UPT UNNES Press

Faisal, Hanafiah. 1982. Format-Format Penelitian Sosial. Jakarta . Raja Grafindo Persada

Iswandi. 2012. Ekologi dan Ilmu Lingkungan. Padang:UNP Press.

Slamet, Juli. 2002. Kesehatan Lingkungan. Bandung: Gajah Mada University Press

Sugiyono. (2005). Metode Penelitian Kuantitaif Kualitatif Dan $R \& D$. Bandung: Alfabeta

Sukarni, Mariyati. 1994. Kesehatan Lingkungan. Bandung; Gajah Mada University Press

Suparlan. 1981. Pendidikan Lingkungan Sosial Budaya dan Teknologi. Jakarta: Universitas

Purwanto, Heri. 1999. Pendekatan Perilaku Manusia. Jakarta: PT. Rineka Cipta 